\title{
Deteksi Manusia menggunakan Pre-Trained MobileNet untuk Segmentasi Citra Menentukan Bentuk Tubuh
}

\author{
IRMA AMELIA DEWI, FARHAN RAFIQI \\ Program Studi Informatika, Institut Teknologi Nasional Bandung \\ Email : irma_amelia@itenas.ac.id \\ Received 30 Maret 2019 | Revised 20 April 2019 | Accepted 15 Mei 2019
}

\begin{abstract}
ABSTRAK
Pakaian merupakan kebutuhan semua orang, karena pakaian adalah kebutuhan pokok manusia selain pangan (makanan) dan papan (tempat tinggal). Kebutuhan fashion merupakan kebutuhan manusia dimana dia menggunakan pakaian yang nyaman sesuai dengan bentuk badannya sebagai bentuk mengekspresikan dirinya terhadap orang lain. Maka dari itu penelitian ini dibuat agar mengetahui rekomendasi pakaian berdasarkan bentuk badannya. Sistem yang akan dibangun terdiri dari 2 alur proses yaitu deteksi tubuh menggunakan pre-trained MobileNetV2 dan penentuan bentuk badan dengan pembagian 19 garis pada citra tubuh untuk mendapatkan lebar bahu, pinggang dan panggul lalu dilakukan perbandingan sehingga didapatkan bentuk badan dan diberikan rekomendasi baju yang sesuai. Setelah dilakkan pengujian, maka diperoleh akurasi 92,33\% untuk proses deteksi manusia. mencapai 96,06\% dan akurasi hasil deteksi bentuk badan sebesar $82 \%$. Sistem memperoleh keakurasian ukuran nyata dan sistem mencapai 96,06\% pada jarak kamera terhadap objek mencapai 2 meter dengan ketinggan kamera 0,75 meter memperoleh keakurasian ukuran nyata dan sistem
\end{abstract}

Kata kunci: MobileNet, Segmentasi, Bentuk Tubuh

\begin{abstract}
Cloths are a every human needs, because is one of the a basic human need other than food and residence. Fashion are human needs where they wear comfortable clothes that fit with their body shape as a form of expressing themselves to others. Therefore, this study was made in order to find out recommendations for fitting clothes based on body shape. The system have 2 process line, body detection using pre-trained MobileNetV2 and determine body shape by dividing 19 lines in body image to obtain shoulder, waist and hip widths and then compared to get the body shape and appropriate clothing recommendations are given. After the test, an accuracy of $92.33 \%$ was obtained for human detection process. The system achieves $96.06 \%$ accuracy in determining the size that corresponds to the real size when the camera distance from the object reaches 2 meters with a camera height of 0.75 meters, obtaining real size accuracy and the system
\end{abstract}

Keywords: MobileNet, Segmentation, Body Shape

MIND - 65 


\section{PENDAhULUAN}

Kebutuhan fashion merupakan kebutuhan semua orang, karena pakaian adalah kebutuhan pokok manusia selain pangan (makanan) dan papan (tempat tinggal) (Widyosiswoyo, 1991). Manusia membutuhkan pakaian untuk melindungi dan menutup dirinya dari orang lain maupun suatu ancaman. Setiap orang membutuhkan memakai pakaian yang pas dengan badannya agar terasa nyaman dengan pakaian yang dipakai sebagai bentuk mengekspresikan dirinya terhadap orang lain (Monica Stella Angelina, 2015). Maka dari itu penelitian ini dibuat agar mengetahui rekomendasi pakaian yang sesuai berdasarkan bentuk badannya.

Saat ini, teknologi untuk mengenali objek dan mendeteksi bentuk dari pemrosesan citra sudah sering digunakan, terutama dalam bidang industri karena biasa dibutuhkan untuk mengenali bentuk benda yang akan diproduksi oleh mesin. Selain itu, pemrosesan citra dapat digunakan untuk mendeteksi bentuk tubuh manusia dari masukkan berupa foto atau citra dari tubuh manusia tersebut. Sehingga dengan menggunakan teknologi pemrosesan citra, program dapat mendeteksi bentuk tubuh manusia dan dapat membantu untuk memilih pakaian yang akan mereka kenakan dan jenis pakaian yang cocok. Salahsatu metode yang dapat melakukan pemrosesan citra yaitu CNN dengan arsitektur MobileNet.

Pada penelitian ini Mobilenet digunakan untuk mengenali objek pada citra dengan memproses pixel citra sehingga output yang dihasilkan adalah pixel yang sudah terdapat kode pixel hasil deteksi Mobilenet. Setelah diketahui nilai pixel pada array pixel hasil deteksi, maka dilakukan pencarian titik batas atas dan bawah untuk memotong pixel pada citra bagian atas dan bawah tubuh yang tidak terdapat objek manusia. Setelah dilakukan pemotongan, dilakukan pembagian dan pengukuran lebar bagian tubuh untuk mengetahui lebar bahu, pinggang dan panggul. Setelah diketahui lebarnya maka lebar bagian tubuh tersebut dibandingkan lalu diklasifikasikan ke salahsatu bentuk badan yang sesuai dan diberi rekomendasi pakaian untuk bentuk badan tersebut. Dengan penelitian ini diharapkan untuk dapat menentukan fashion style yang sesuai dengan bentuk tubuh/postur tubuh yang diperoleh dari perhitungan mengukur tubuh menggunakan kamera.

\section{METODE PENELITIAN}

Sistem yang akan dibangun adalah penerapan segmentasi citra untuk menentukan bentuk tubuh dan rekomendasi pakaian.

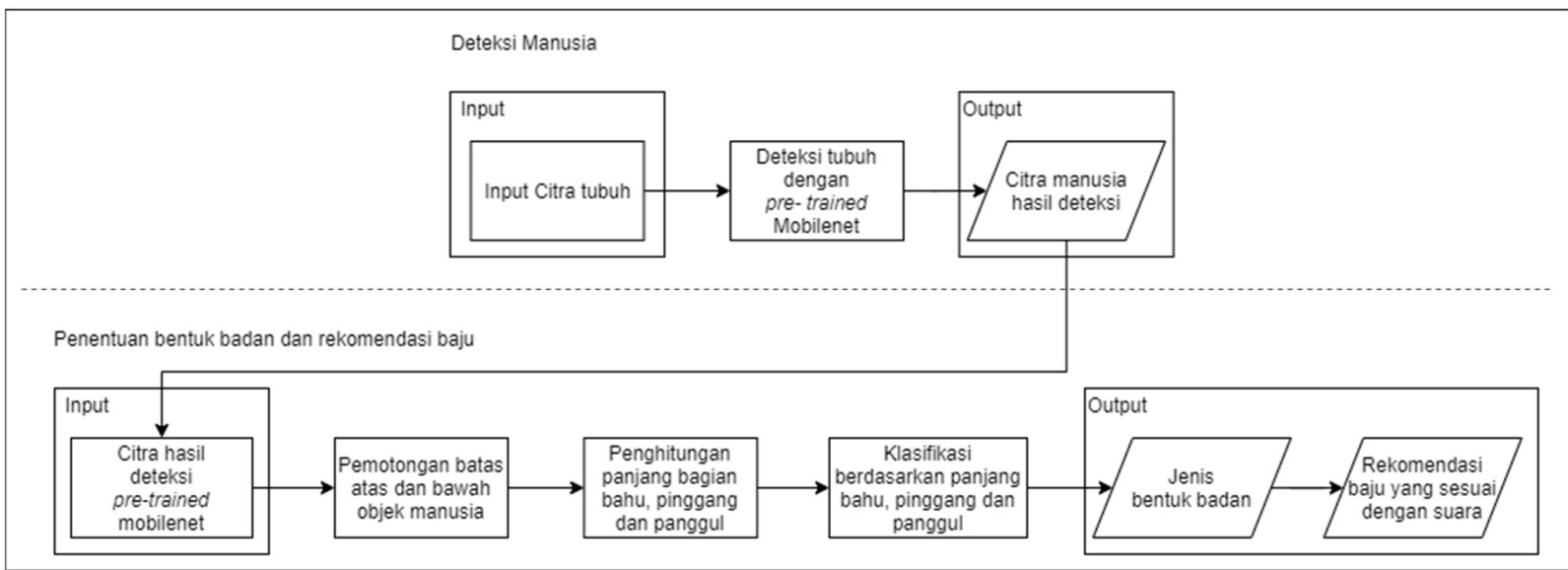

Gambar 1. Blok Diagram Sistem 
Pada proses deteksi manusia, citra input akan dideteksi dengan menggunakan pre-trained Mobilenet sehingga dapat diketahui object apa saja yang terdeteksi oleh sistem. Jika citra terdeteksi terdapat pixel manusia maka proses dilanjutkan dengan penentuan bentuk badan dan memberikan rekomendasi pakaian yang sesuai dengan bentuk tubuh.

\subsection{Pre-Trained Mobilenet}

Pre-Trained adalah suatu model deep learning yang dilatih dengan sebuah data latih yang bertujuan mendapatkan model untuk deteksi sebuah objek. Penelitian ini menggunakan model CNN (Saha, 2018) dengan arsitektur MobileNetV2 (Mark Sandler A. H., 2018) yang telah di training terlebih dahulu menggunakan dataset Pascal VOC2012 (Visual Object Classes 2012). Pascal VOC adalah kumpulan dataset untuk mengenali objek dari sejumlah kelas objek visual dalam adegan realistis. Model ini telah diuji dengan mengenali 21 objek yaitu background, Pesawat terbang, sepedah, burung, kapal laut, botol, bis, mobil, kucing, kursi, sapi, meja makan, anjing, kuda, sepeda motor, manusia, tanaman di pot, domba, sofa, kereta api dan televisi (Everingham, 2012). Sistem di iterasi sebanyak 152,59 Miliyar kali dengan CPU runtime selama 26,9 detik dan mendapatkan akurasi sebesar 80,25\%.

MobileNet memiliki 28 layer, terdiri dari Depthwise Convolution, Batch Normalization kemudian layer ReLu (Rectified Linear Unit), setelah itu dilakukan Pointwise Convolution dilakukan lagi Batch Normalization kemudian ReLu (Rectified Linear Unit)

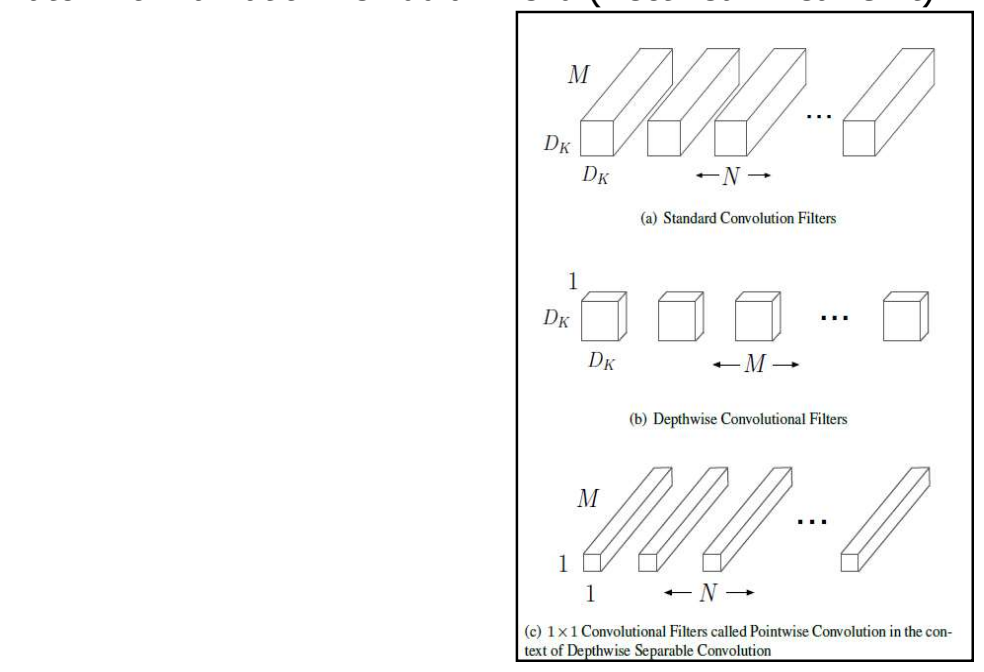

Gambar 2. Konvolusi standard (a) depthhwise convolution (b) pointwise convolution (c) Sumber : (Andrew G. Howard, 2017)

MobileNet mengganti lapisan konvolusional standard dengan blok depthwise convolution dimana setiap blok terdiri dari lapisan konvolusional $3 \times 3$ yang menyaring input, diikuti oleh pointwise convolution $1 \times 1$ yang menggabungkan nilai-nilai yang difilter untuk menciptakan sebuah fitur baru.

Batch Normalization adalah teknik untuk deep neural network untuk membuat standard inputan kepada layer untuk setiap batch kecil (Brownlee, 2019). Fungsi ini memberikan efek menstabilkan proses pembelajaran sistem dan sangat berpengaruh untuk mengurangi epoch training yang dibutuhkan untuk melatih model deep learning.

ReLU (Rectified Linear Unit) merupakan fungsi linear yang digunakan untuk mengubah nilai $\mathrm{x}$ menjadi 0 jika $\mathrm{x}$ bernilai asal negatif dan tetap mempertahankan nilai $\mathrm{x}$ jika bernilai lebih dari 0. Fungsi ReLu pertama kali diperkenalkan oleh Geoffrey Hinton dan Vinod Nair untuk menggantikan fungsi aktivasi sigmoid (Pedomanti, 2018).

$$
\text { MIND - } 67
$$


Operasi diatas akan berulang sehingga setiap pixel pada citra input akan mempunyai output berupa nilai matriks kode hasil klasifikasi berdasarkan Pascal VOC2012. Hasil keluaran citra pada sistem ini memiliki tinggi 512 pixel dan lebar citra mengikuti lebar input citra

Berikut merupakan contoh input dan output citra pada sistem

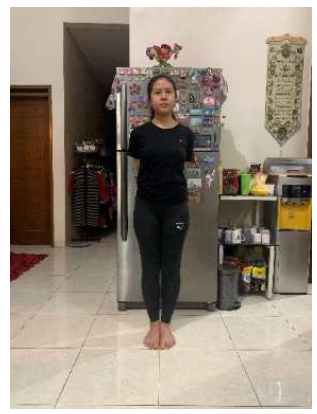

Gambar 3. Kasus Citra Input

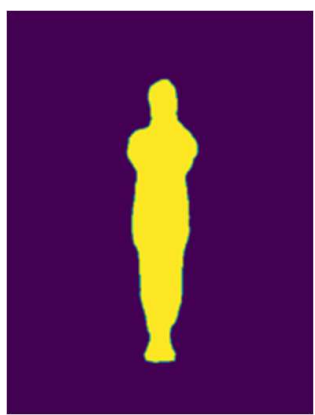

Gambar 4. Hasil Output Proses Segmentasi

Output pada sistem Mobilenet merupakan matrik pixel yang telah diberi kode sesuai dengan objek yang terdeteksi pada citra tersebut. Menurut Pascal VOC2012, nilai 0 pada matriks adalah dideteksi sebagai objek sedangkan 15 merupakan dideteksi sebagai objek manusia.

Pada Gambar 3, output citra yang dihasilkan terdapat nilai pixel 0 dan 15 . Untuk mengilustrasikan pixel pada citra, maka dibuat contoh kasus pada Gambar 4

\begin{tabular}{|c|c|c|c|c|c|c|c|c|c|c|c|c|c|c|}
\hline 0 & 0 & 0 & 0 & 0 & 0 & 0 & 0 & 0 & 0 & 0 & 0 & 0 & 0 & 0 \\
\hline 0 & 0 & 0 & 0 & 0 & 0 & 0 & 0 & 0 & 0 & 0 & 0 & 0 & 0 & 0 \\
\hline 0 & 0 & 0 & 0 & 0 & 0 & 0 & 0 & 0 & 0 & 0 & 0 & 0 & 0 & 0 \\
\hline 0 & 0 & 0 & 15 & 15 & 15 & 15 & 15 & 15 & 15 & 15 & 0 & 0 & 0 & 0 \\
\hline 0 & 15 & 15 & 15 & 15 & 15 & 15 & 15 & 15 & 15 & 15 & 15 & 15 & 0 & 0 \\
\hline 15 & 15 & 15 & 15 & 15 & 15 & 15 & 15 & 15 & 15 & 15 & 15 & 15 & 15 & 0 \\
\hline 15 & 15 & 15 & 15 & 15 & 15 & 15 & 15 & 15 & 15 & 15 & 15 & 15 & 15 & 15 \\
\hline 15 & 15 & 15 & 15 & 15 & 15 & 15 & 15 & 15 & 15 & 15 & 15 & 15 & 15 & 15 \\
\hline 15 & 15 & 15 & 15 & 15 & 15 & 15 & 15 & 15 & 15 & 15 & 15 & 15 & 15 & 15 \\
\hline 15 & 15 & 15 & 15 & 15 & 15 & 15 & 15 & 15 & 15 & 15 & 15 & 15 & 15 & 15 \\
\hline 15 & 15 & 15 & 15 & 15 & 15 & 15 & 15 & 15 & 15 & 15 & 15 & 15 & 15 & 15 \\
\hline 15 & 15 & 15 & 15 & 15 & 15 & 15 & 15 & 15 & 15 & 15 & 15 & 15 & 15 & 15 \\
\hline 15 & 15 & 15 & 15 & 15 & 15 & 15 & 15 & 15 & 15 & 15 & 15 & 15 & 15 & 15 \\
\hline 15 & 15 & 15 & 15 & 15 & 15 & 15 & 15 & 15 & 15 & 15 & 15 & 15 & 15 & 15 \\
\hline 15 & 15 & 15 & 15 & 15 & 15 & 15 & 15 & 15 & 15 & 15 & 15 & 15 & 15 & 15 \\
\hline
\end{tabular}

Gambar 5. Nilai Pixel Output

Pada Gambar 4. Output pixel tersebut menurut dataset Pascal VOC2012, kode 0 pada matriks adalah dideteksi sebagai objek sedangkan 15 merupakan dideteksi sebagai objek manusia. Area warna ungu merupakan background sementara area warna kuning menandakan objek manusia. Pada proses berikutnya dilakukan proses menghilangkan background pada area atas kepala dan background bawah kaki.

\subsection{Proses Pencarian Titik Batas dan Pemotongan}

Proses searching menggunakan pencarian secara iteratif. Proses ini dilakukan untuk mengetahui titik-titik tertentu pada matriks segmentasi citra. Adapun titik-titik yang diperlukan dalam sistem ini adalah sebagai berikut :

\subsubsection{Batas atas kepala}

Dimulai dari koordinat $(i, j)$ dimana $\mathrm{j}$ adalah lebar pixel citra dibagi 2 , sedangkan i dimulai dari koordinat 0 dan dilakukan iterasi +1 jika pada sumbu $(I, j)$ tidak terdapat pixel manusia. 
Deteksi Manusia menggunakan Pre-Trained MobileNet untuk Segmentasi Citra Menentukan Bentuk Tubuh

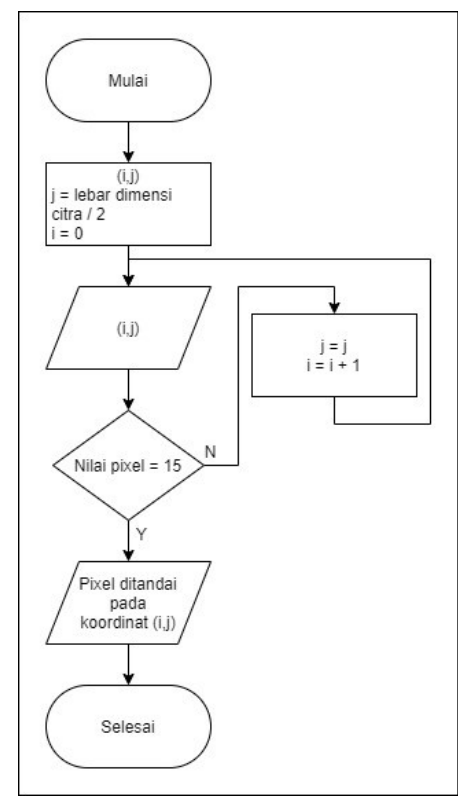

Gambar 6. Flowchart Deteksi Batas Atas

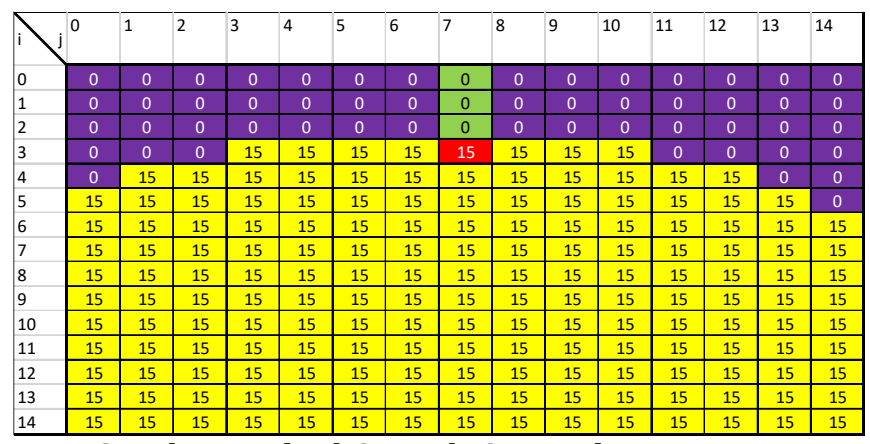

Gambar 7 Pixel Contoh Operasi Batas Atas

Dimulai dari koordinat $(i, j)$ dimana $\mathrm{j}=15 / 2=7,5$ yang dibulatkan kebawah menjadi 7 , sedangkan y dimulai dari koordinat 0 . Pada contoh kasus Gambar 6 , pada pixel koordinat $(0,7)$ tidak terdapat angka 15 sehingga dilakukan operasi penambahan $\mathrm{i}=\mathrm{i}+1$ seperti pada Gambar 5 dimana koordinatnya berubah menjadi $(1,7)$. Lalu operasi tersebut diulang hingga pada Gambar 6 pada koordinat $(3,7)$ pixel berisi angka 15 sehingga pada koordinat tersebut diberi tanda.

\subsubsection{Batas bawah kaki}

Dimulai pencarian dari titik kooridinat $(i, j)$ dimana i merupakan nilai koordinat vertical terbesar pada citra. Lalu sumbu j adalah titik koordinat 0 pada matriks yang dilakukan iterasi +1 hingga mendapatkan pixel berisi kode manusia atau sampai mencapai lebar maksimal dari citra. Jika j mencapai lebar maksimal pixel, maka nilai j dikembalikan menjadi 0 dan nilai i dikurangi 1.

Dimulai pencarian dari titik kooridinat $(j, j)$ dimana y merupakan nilai koordinat vertikal terbesar pada citra. Pada contoh kasus Gambar 8, koordinat dimulai dari $(14,0)$ karena tinggi dimensi citra adalah 14 pixel. Pada koordinat $(14,0)$ tidak terdeteksi adnya pixel dengan nilai 15 sehingga menurut Gambar 7 jika tidak terdapat angka 15 pada pixel dan $\mathrm{j}$ belum menyantuh lebar pixel citra, maka $j=j+1$ sehingga pixel yang dideteksi bergeser menjadi $(14,1)$. Jika pengecekan sudah menyentuh koordinat $(14,14)$ dan belum terdeteksi adanya nilai 15 pada pixel, maka nilai $\mathrm{j}$ menjadi 0 dan nilai $\mathrm{i}=\mathrm{i}-1$ sehingga pada contoh kasus ini pencarian 
dimulai kembali dari pixel $(13,0)$ begitu seterusnya hingga pada koordinat $(11,6)$ terdeteksi adanya nilai pixel 15 sehingga pada contoh kasus ini pixel pada titik koordinat $(11,6)$ diberi tanda. Setelah proses pencarian titik-titik yang diperlukan telah didapat, maka hasilnya akan seperti ini

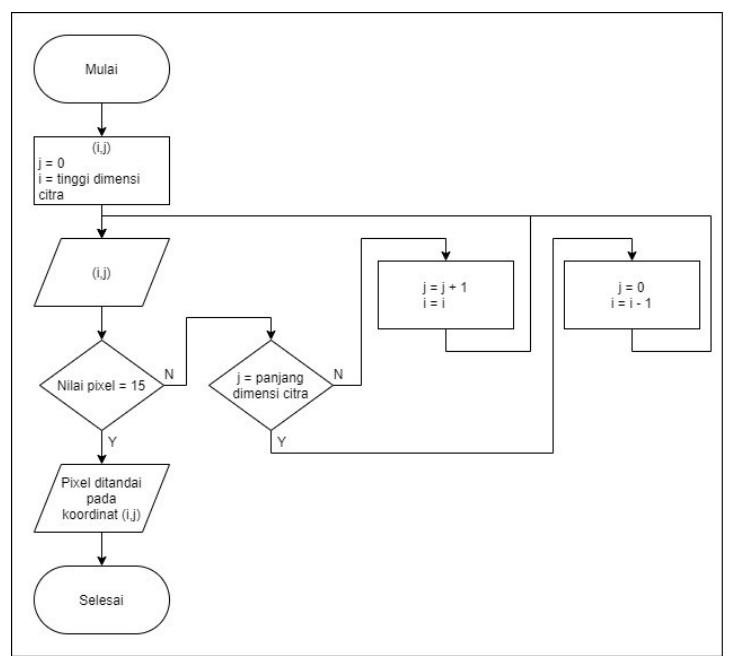

\section{Gambar 8. Flowchart Deteksi Batas Bawah}

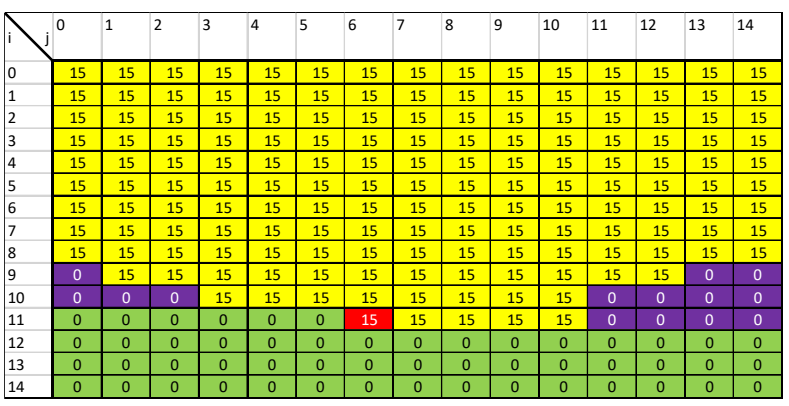

Gambar 9. Pixel Contoh Operasi Batas Bawah

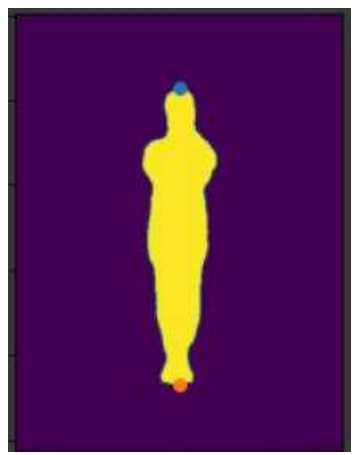

\section{Gambar 10. Citra Hasil Pemberian Tanda Pada Titik Yang Diperlukan}

Pada Gambar 9, titik-titik batas kepala dan kaki sudah ditemukan lalu dilakukan pemotongan pada pixel citra bagian atas dan bagian bawah. 
Deteksi Manusia menggunakan Pre-Trained MobileNet untuk Segmentasi Citra Menentukan Bentuk Tubuh

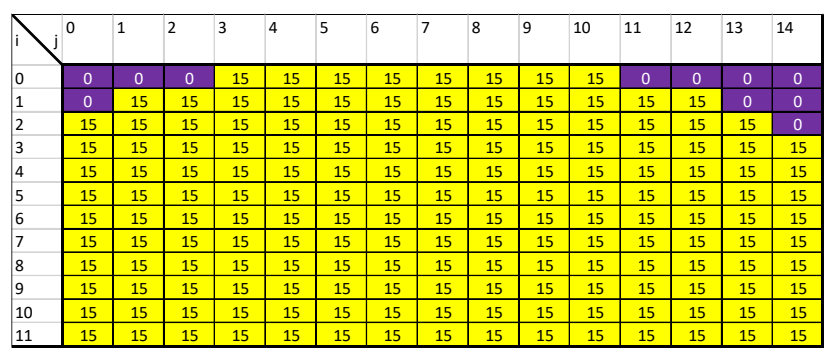

Gambar 11. Pixel Hasil Pemotongan Batas Atas

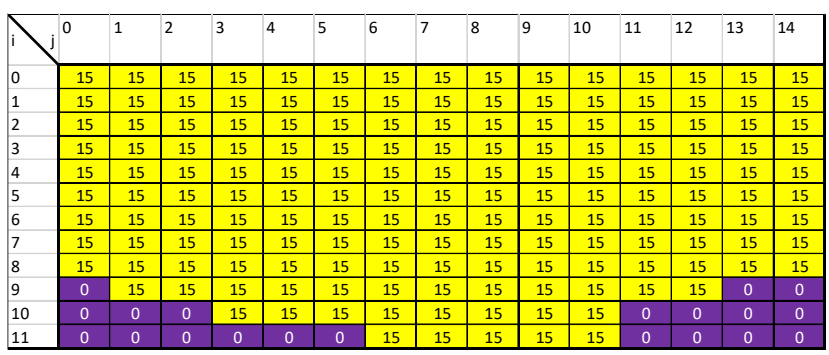

Gambar 12. Pixel Hasil Pemotongan Batas Bawah

Pada Gambar 10 dan 11, batas atas dan bawah sudah dipotong untuk mempermudah proses selanjutnya.

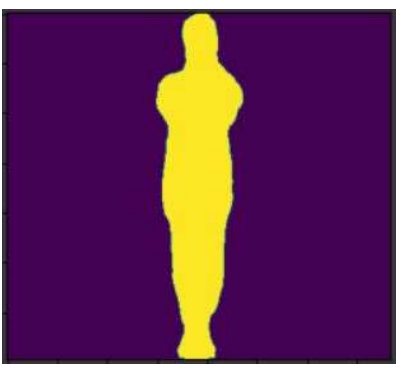

\section{Gambar 13. Citra Hasil Pemotongan}

Gambar 12 memperlihatkan citra hasil pemotongan berdasarkan titik yang telah dibuak background bagian atas dan bawah objek manusia.

\subsection{Proses Penentuan Garis Bahu, Pinggang dan Panggul Beserta Lebarnya}

Penentuan garis bentuk badan dilakukang dengan membagi citra yang telah dipotong pada proses berikutnya menjadi 19 bagian (D. M. Anisuzzaman, 2019) dengan cara membagi rata tinggi citra menjadi 19 bagian. Jika diberi contoh kasus tinggi citra yang telah terpotong, tinggi pixel nya adalah 190 maka, pembagiannya menjadi $190 / 19=10$. Yang artinya setiap 10 pixel, akan diberikan garis berupa penanda bagian- bagian tubuh tersebut.

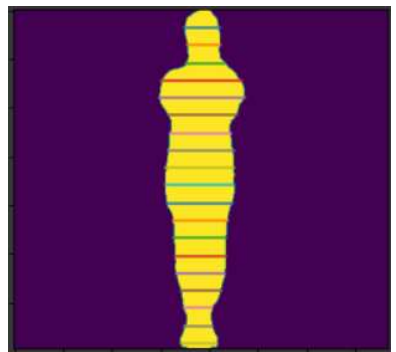

Gambar 14. Citra Hasil Pembagian 19 Garis 
Garis penanda 19 bagian pada Gambar 13 hanya diberikan pada bagian tubuh yang terdeteksi sekaligus memberikan lebar garis tersebut sehingga diketahui lebar pixel dari masing-masing garis. Garis dimulai berurutan dari atas citra berurut hingga garis ke 19 pada kaki.

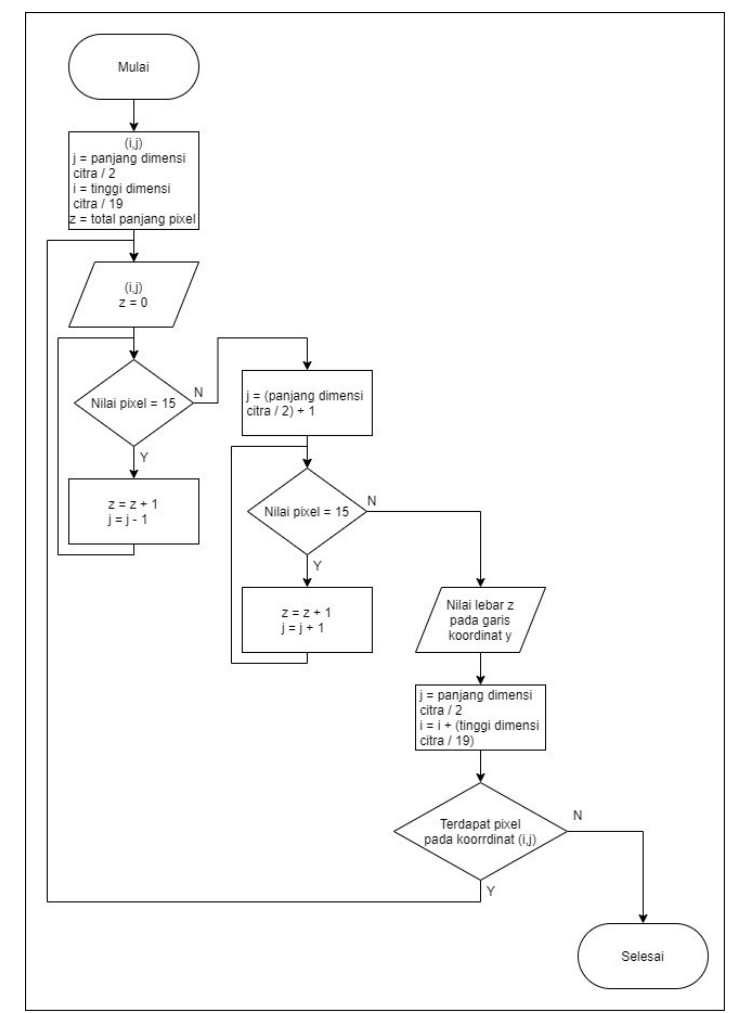

\section{Gambar 15. Flowchart Pembagian Garis Dan Lebar Pixel Tiap Garis}

Gambar 14 memperlihatkan alur cara pembagian garis dan perhitungan lebar pixel yang dilakukan dari tengah ke kiri lalu tengah +1 ke kanan.

$$
\begin{gathered}
j=\frac{\text { panjang dimensi citra }}{2} \\
i=\frac{\text { tinggi dimensi citra }}{19}
\end{gathered}
$$

Bila ada contoh kasus citra dengan ukuran $100 \times 190$ pixel maka menurut Persamaan 1 dan Persamaan 2, j = $100 / 2=50$ dan $\mathrm{i}=190 / 19=10$. Artinya setiap 10 pixel akan diberikan tanda dan lebar garis adalah z pixel. Jika pada koordinat $(10,51)$ nilai pixelnya 15 , maka nilai $z$ akan bertambah 1 dan koordinat $\mathrm{j}$ akan dikurang 1 . Begitu seterusnya hingga tidak terdapat nilai pixel 15 pada koordinat $(i, j)$.

$$
\begin{aligned}
& j=\frac{\text { panjang dimensi citra }}{2}+1 \\
& i=i+\frac{\text { tinggi dimensi citra }}{19}
\end{aligned}
$$

Misalkan pada koordinat $(10,30)$ tidak terdapat nilai pixel 15 , maka menurut Persamaan 4 nilai j akan diubah menjadi $\mathrm{j}=(100 / 2)+1=51$ Pada titik koordinat $(10,51)$ bila nilai pixel terdeteksi maka $z=z+1$ dan $j=j+1$. Begitupun seterusnya hingga tidak terdapat nilai pixel 
15 pada koordinat $(i, j)$. misalkan pada koordinat $(10,70)$ tidak terdapat nilai pixel 15 , maka didapatkan pada garis koordinat $\mathrm{i}=10$ lebar garisnya adalah z pixel. Setelah didapatkan itu lalu dilanjutkan dengan pergantian nilai menurut Persamaan 1 dan Persamaan 4 sehingga $j$ $=100 / 2=50, \mathrm{i}=10+(190 / 19)=20$, dan $z=0$

Jika pada koordinat $(20,10)$ masih termasuk kedalam pixel citra tersebut, maka terus dilakukan pengulangan hingga titik koordinat tidak terdapat pada citra.

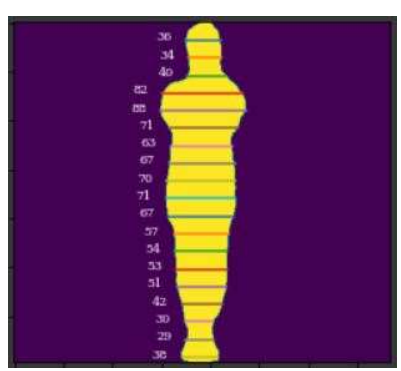

\section{Gambar 16. Hasil Pembagian Garis Dan Lebar Pixel Tiap Garis}

Pada Gambar 15 memperlihatkan pembagian garis dan terdapat angka di bagian kiri garis yang menandakan lebar tiap garis dengan satuan pixel. Menurut (D. M. Anisuzzaman, 2019), garis yang mewakili bagian bahu, pinggang dan panggul adalah garis nomor 4 sebagain lebar bahu, garis nomor 8 sebagai lebar pinggang dan garis nomor 10 sebagai lebar panggul. Maka diambil data tersebut dari contoh kasus Gambar 15.

\subsection{Klasifikasi bentuk badan}

Pada proses ini, sistem hanya mengambil 3 bagian dari 19 garis yang sudah dibagi.

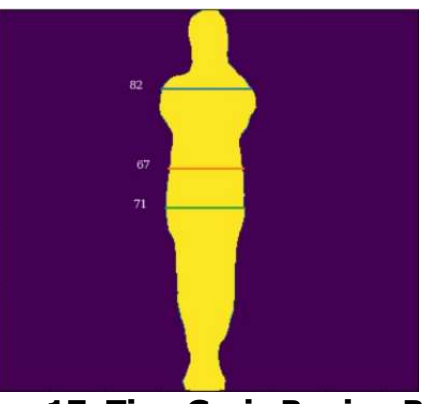

\section{Gambar 17. Tiga Garis Bagian Badan}

Pada Gambar 16, sudah didapatkan nilai lebar bahu yaitu 82 pixel, lebar pinggang 67 pixel dan lebar panggul 71 pixel. Sehingga dapat dilakukan perbandingan sehingga didapatkan bentuk badan yang sesuai.

Pada Gambar 17, menampilkan flowchart bagaimana sistem klasifikasi menggunakan metode Classification and Resgresion Tree(CART). CART adalah model prediksi menggunakan struktur pohon atau struktur berhirarki (Loh, 2014). Pada sistem ini digunakan metode tersebut untuk mengklasifikasi bentuk tubuh berdasarkan perbandingan antara lebar bahu, pinggang dan panggul. Bila diambil contoh kasus pada Gambar 17 yang telah diketahui

- Lebar bahu = 82 pixel

- Lebar Pinggang = 67 pixel

- Lebar panggul = 71 pixel

Menurut (Karla Simmons, 2004), Jenis tubuh wanita dibedakan menjadi 5 jenis. Ada yang berbentuk oval/apple " $\mathrm{O}$ ", hourglass " $\mathrm{X}$ ", triangle/pear " $\mathrm{A}$ ", persegi " $\mathrm{H}$ ", dan segitiga terbalik "V". Lima bentuk tersebut dibedakan berdasarkan perbandingan antara ukuran bahu, pinggang dan panggul. Bila lebar bahu lebih kecil daripada lebar panggul maka termasuk 
bentuk badan segitiga, bila lebar bahu lebih besar daripada lebar panggul maka termasuk bentuk badan segitiga terbalik. Jika lebar bahu dan panggul sama, maka ada perbandingan dengan lebar pinggang, bila lebar bahu dan panggul lebih besar daripada pinggang maka termasuk bentuk badan hourglass, jika lebar bahu dan panggul lebih pendek daripada pinggang maka termasuk bentuk oval, jika lebar bahu, pinggang, dan panggul sama, maka dikategorikan bentuk badan persegi.

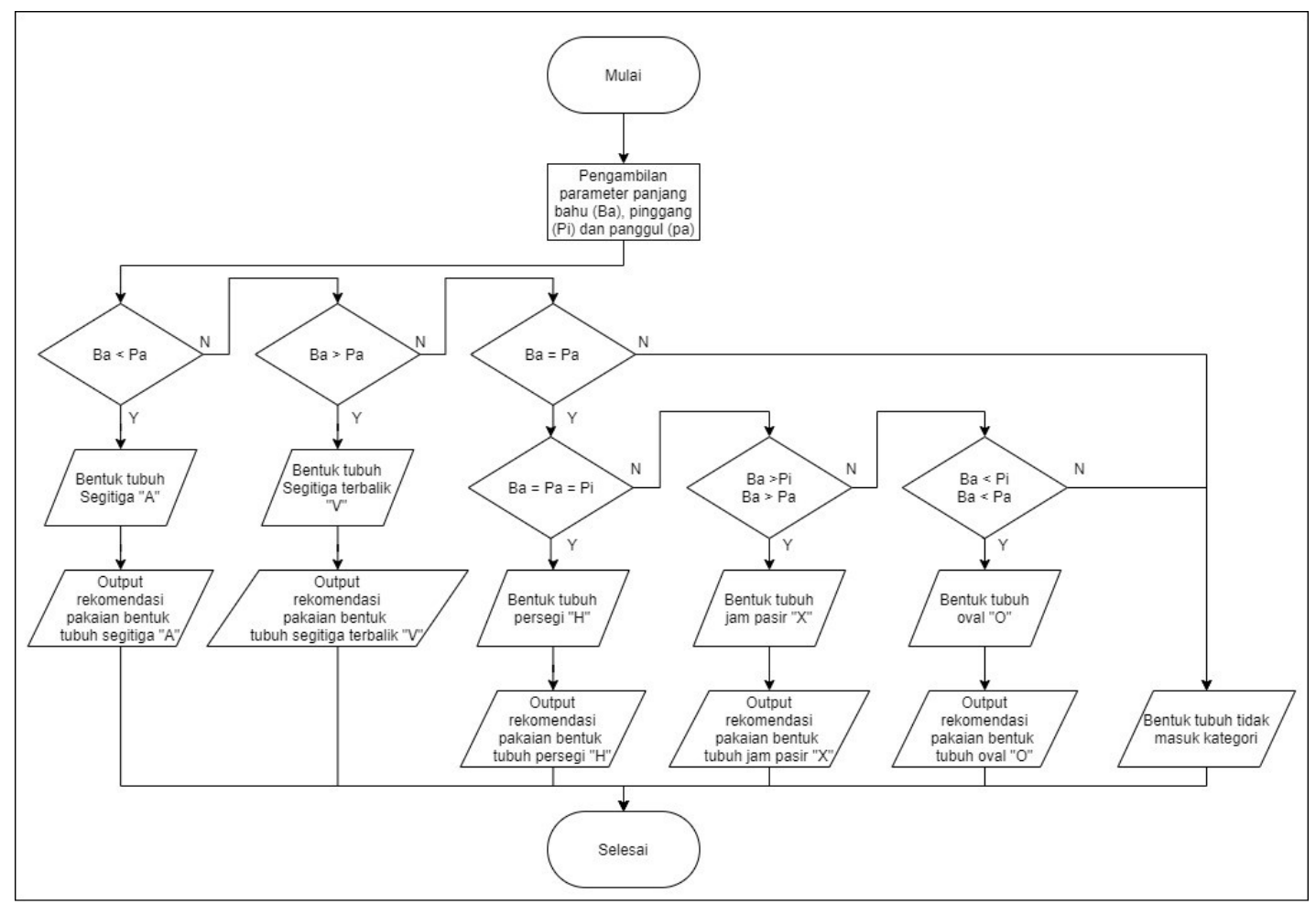

Gambar 18. Flowchart Deteksi Bentuk Badan

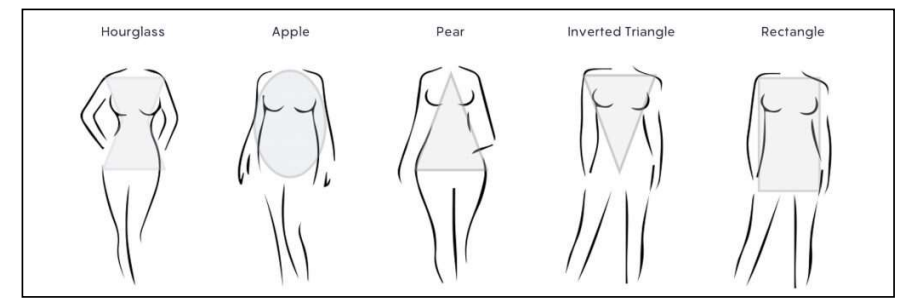

Gambar 19. Jenis Bentuk Badan

Sumber : (Koukoravas, 2018)

Jika merujuk pada Gambar 18 dan mengambil data dari Gambar 16 bahwa lebar bahu lebih lebar dibandingkan dengan lebar panggul maka, bentuk badan menurut Gambar 17 adalah bentuk tubuh segitiga terbalik " $\mathrm{V}$ ". Karena bila lebar bahu lebih besar dibandingkan lebar panggul, maka dapat dikategorikan sebagai bentuk tubuh segitiga terbalik.

\section{HASIL DAN PEMBAHASAN}

Pada sistem ini dilakukan 4 jenis pengujian dengan scenario dan tujuan yang berbeda

Tabel 1. Skenario Pengujian

\begin{tabular}{|c|c|c|}
\hline No. Pengujian & Skenario Pengujian & Hasil \\
\hline 1 & $\begin{array}{c}\text { Melakukan pengujian deteksi manusia } \\
\text { pada sistem dengan input berupa citra }\end{array}$ & $\begin{array}{c}\text { Mendapatkan nilai akurasi, presisi, } \\
\text { recall, dan F1 score }\end{array}$ \\
\hline
\end{tabular}


Deteksi Manusia menggunakan Pre-Trained MobileNet untuk Segmentasi Citra Menentukan Bentuk Tubuh

\begin{tabular}{|c|c|c|}
\hline 2 & $\begin{array}{c}\text { Melakukan 20 kali pengambilan citra } \\
\text { tubuh manusia dengan jarak dan } \\
\text { ketinggian kamera yang berbeda }\end{array}$ & $\begin{array}{c}\text { Mendapatkan jarak dan ketinggian } \\
\text { kamera yang optimal dan } \\
\text { mendapat rasio perbandingan } \\
\text { optimal pada sistem }\end{array}$ \\
\hline 3 & $\begin{array}{c}\text { Melakukan pembagian yang berbeda } \\
\text { untuk segmentasi bentuk tubuh }\end{array}$ & $\begin{array}{c}\text { Mendapatkan hasil pembagian } \\
\text { manusia yang optimal }\end{array}$ \\
\hline 4 & $\begin{array}{c}\text { Melakukan klasifikasi hasil dari } \\
\text { perbandingan lebar panggul, pinggang } \\
\text { dan panggul }\end{array}$ & $\begin{array}{c}\text { Mendapatkan akurasi klasifikasi } \\
\text { bentuk badan manusia }\end{array}$ \\
\hline
\end{tabular}

\subsection{Pengujian Deteksi Manusia menggunakan pretrained Mobilenet}

Untuk mengukur kerja sistem dilakukan pengujian dengan menghitung nilai akurasi, presisi, recall dan F1 score. Persamaan nilai akurasi, presisi, recall dan F1 score sebagai berikut :

$$
\begin{gathered}
\text { Akurasi }=\frac{(T P+T N)}{(T P+F P+F N+T N)} \\
\text { Presisi }=\frac{(T P)}{(T P+F P)} \\
\text { Recall }=\frac{(T P)}{(T P+F N)} \\
\text { F1 Score }=2 * \frac{(\text { Recall } * \text { Presisi })}{(\text { Recall }+ \text { Presisi })}
\end{gathered}
$$

Keterangan :

- $\mathrm{TP}=$ True Positive jika input citra terdapat manusia dan dibaca terdapat manusia oleh sistem

- $\quad \mathrm{TN}=$ True Negative jika input citra tidak terdapat manusia dan dibaca tidak terdapat manusia oleh sistem

- $\mathrm{FP}=$ False Positive Jika input citra tidak terdapat manusia tetapi dibaca terdapat manusia oleh sistem

- $\quad \mathrm{FN}=$ False Negative jika input citra terdapat manusia tetapi dibaca tidak terdapat manusia oleh sistem.

Data citra yang terdapat objek manusia didapatkan secara online, hasil foto langsung, CrowdHuman (Shuai Shao, 2018) dan human detection database (Kaggle) dengan total sebanyak 200 citra.

Tabel 2 Sumber Data Pengujian Deteksi Objek Manusia

\begin{tabular}{|c|c|c|c|c|c|}
\hline Na & Gumban Rato & & & & \\
\hline No & Sumber Data & TP & TN & FP & $\mathbf{F I}$ \\
\hline
\end{tabular}

\begin{tabular}{|c|c|c|}
\hline No. & Sumber Data & Jumlah Sample \\
\hline 1 & $\begin{array}{c}\text { Online dan hasil foto } \\
\text { langsung }\end{array}$ & 100 Citra \\
\hline 2 & $\begin{array}{c}\text { Human Detection Database } \\
\text { Kaggle }\end{array}$ & 50 Citra \\
\hline 3 & $\begin{array}{c}\text { CrowdHun (Shuai Shao, } \\
2018)\end{array}$ & 50 Citra \\
\hline
\end{tabular}

Berikut merupakan tabel hasil pengujian deteksi manusia

Tabel 3. Hasil Perhitugan Pengujian Deteksi Manusia 


\begin{tabular}{|c|c|c|c|c|c|c|c|c|c|}
\hline 1 & $\begin{array}{c}\text { Online dan hasil foto } \\
\text { langsung }\end{array}$ & 93 & 4 & 0 & 3 & $97,0 \%$ & $100 \%$ & $96,9 \%$ & $98,411 \%$ \\
\hline 2 & $\begin{array}{c}\text { Human Detection } \\
\text { Database (Kaggle) }\end{array}$ & 41 & 0 & 0 & 9 & $82,0 \%$ & $100 \%$ & $82,0 \%$ & $90,11 \%$ \\
\hline 3 & $\begin{array}{c}\text { CrowdHuman (Shuai } \\
\text { Shao, 2018) }\end{array}$ & 49 & 0 & 0 & 1 & $98,00 \%$ & $100 \%$ & $98,0 \%$ & $98,99 \%$ \\
\hline
\end{tabular}

Dari pengujian ini diperoleh akurasi $97,00 \%$ oleh sumber data online dan hasil foto langsung, 82,0\% dari Human Detection Database, dan 98,0\% dari CrowdHuman. Akurasi tersebut lebih tinggi dibandingkan dengan pre-trained Mobilenet ini yang sudah dilakukan pengujian terlebih dahulu dengan data uji Pascal VOC dengan akurasi $80.25 \%$. Akurasi berbeda dikarenakan keragaman citra yang terdapat pada masing-masing data uji. Ketidaksempurnaan akurasi dikarenakan citra yang terlalu gelap atau buram, dan objek manusia yang terlalu kecil dan berbaur dengan background sehingga sistem tidak dapat mengenali adanya manusia.

\subsection{Pengujian Jarak, Ketinggian Kamera dan Perbandingan Ukuran}

Pada pengujian ini sistem diberi input berupa citra dengan jarak pengambilan dan ketinggian kamera yang berbeda dengan posisi kamera straight angel (sudut kamera lurus) dan dibandingkan dengan ukuran lebar aslinya. Citra diambil dari jarak 1,5-2 meter dengan ketinggian kamera 1-0,75 meter. Lalu hasil tersebut akan dibandingkan ukuran pada pixel dikali dengan konversi pixel ke $\mathrm{cm}$.

$$
\text { tPixel }=(\text { tinggi badan }(\mathrm{cm})) /(\text { tinggi badan }(\text { pixel }))
$$

Dimana tPixel merupakan faktor pengali untuk konversi. Jika diberi contoh kasus pada Persamaan 4.5, tinggi asli seseorang $150 \mathrm{~cm}$ lalu ketika dideteksi oleh sistem tingginya 400 pixel maka faktor pengali pada sistem adalah 0,375 yang artinya setiap 1 pixel pada citra sama dengan $0,375 \mathrm{~cm}$ pada tinggi asli.

Tabel 4. Faktor Pengali Sistem

\begin{tabular}{|c|c|c|}
\hline \multicolumn{2}{|c|}{ Jarak (Meter) } & \multirow{2}{*}{ Faktor Pengali } \\
\hline Objek & Ketinggian Kamera & 0,397 \\
\hline 1,5 & 1 & 0,392 \\
\hline 1,5 & 0,75 & 0,461 \\
\hline 1,75 & 1 & 0,457 \\
\hline 1,75 & 0,75 & 0,518 \\
\hline 2 & 1 & 0,510 \\
\hline 2 & 0,75 & \\
\hline
\end{tabular}

Dari data diatas, diberi contoh kasus jika lebar sebuah bahu lebar aslinya $35 \mathrm{~cm}$ lalu pada pixel terdeteksi 94 pixel, dan citra tersebuat diambil pada jarak objek 1,5m dengan ketinggian kamera $1 \mathrm{~m}$ maka 94 pixel dikali dengan faktor pengali pada jarak tersebut yaitu 0,397 sehingga mendapatkan hasil 37,32cm oleh sistem.

Tabel 5. Hasil Pengujian Perbandingan Lebar Asli dengan Pixel

\begin{tabular}{|c|c|c|c|c|c|c|c|c|}
\hline \multirow{2}{*}{ Pengujian } & \multicolumn{2}{|c|}{ Jarak (Meter) } & \multirow{2}{*}{$\begin{array}{c}\text { Bagian } \\
\text { Tubuh }\end{array}$} & \multicolumn{2}{|c|}{$\begin{array}{c}\text { Lebar Bagian } \\
\text { Tubuh (cm) }\end{array}$} & \multirow{2}{*}{$\begin{array}{c}\text { Selisi } \\
h\end{array}$} & \multirow{2}{*}{$\begin{array}{c}\text { Akurasi } \\
\text { (\%) }\end{array}$} & \multirow{2}{*}{$\begin{array}{c}\text { Rata- } \\
\text { Rata } \\
\text { Akurasi } \\
(\%)\end{array}$} \\
\hline & Objek & $\begin{array}{c}\text { Ketinggian } \\
\text { Kamera }\end{array}$ & & $A s / i$ & $\begin{array}{c}\text { Hitung } \\
\text { an }\end{array}$ & & & \\
\hline \multirow{3}{*}{1} & \multirow{3}{*}{1,5} & \multirow{3}{*}{1} & Bahu & 35 & 37,32 & 2,32 & $93,37 \%$ & \multirow{3}{*}{$91,49 \%$} \\
\hline & & & Pinggang & 27 & 30,97 & 3,97 & $85,30 \%$ & \\
\hline & & & Panggul & 32 & 33,35 & 1,35 & $95,78 \%$ & \\
\hline 2 & 1,5 & 0,75 & Bahu & 35 & 36,47 & 1,47 & $95,80 \%$ & $93,19 \%$ \\
\hline
\end{tabular}


Deteksi Manusia menggunakan Pre-Trained MobileNet untuk Segmentasi Citra Menentukan Bentuk Tubuh

\begin{tabular}{|c|c|c|c|c|c|c|c|c|}
\hline & & & Pinggang & 27 & 30,59 & 3,59 & $86,71 \%$ & \\
\hline & & & Panggul & 32 & 32,94 & 0,94 & $97,06 \%$ & \\
\hline \multirow{3}{*}{3} & \multirow{3}{*}{1,75} & \multirow{3}{*}{1} & Bahu & 35 & 37,81 & 2,81 & $91,97 \%$ & \multirow{3}{*}{$91,75 \%$} \\
\hline & & & Pinggang & 27 & 30,89 & 3,89 & $85,58 \%$ & \\
\hline & & & Panggul & 32 & 32,74 & 0,74 & $97,69 \%$ & \\
\hline \multirow{3}{*}{4} & \multirow{3}{*}{1,75} & \multirow{3}{*}{0,75} & Bahu & 35 & 36,57 & 1,57 & $95,51 \%$ & \multirow{3}{*}{$94,02 \%$} \\
\hline & & & Pinggang & 27 & 30,63 & 3,63 & $86,56 \%$ & \\
\hline & & & Panggul & 32 & 32,00 & 0,00 & $100,00 \%$ & \\
\hline \multirow{3}{*}{5} & \multirow{3}{*}{2} & \multirow{3}{*}{1} & Bahu & 35 & 36,25 & 1,25 & $96,44 \%$ & \multirow{3}{*}{$93,24 \%$} \\
\hline & & & Pinggang & 27 & 30,55 & 3,55 & $86,85 \%$ & \\
\hline & & & Panggul & 32 & 33,14 & 1,14 & $96,44 \%$ & \\
\hline \multirow{3}{*}{6} & \multirow{3}{*}{2} & \multirow{3}{*}{0,75} & Bahu & 35 & 35,16 & 0,16 & $99,55 \%$ & \multirow{3}{*}{$96,06 \%$} \\
\hline & & & Pinggang & 27 & 29,55 & 2,55 & $90,54 \%$ & \\
\hline & & & Panggul & 32 & 32,61 & 0,61 & $98,09 \%$ & \\
\hline
\end{tabular}

Dari hasil pengujian pada Tabel 4 dapat disimpulkan bahwa citra dengan rata-rata akurasi terbesar didapatkan pada pengujian 6 dengan jarak objek 2 meter dengan ketinggian kamerra 0,75 meter.

\subsection{Pengujian Segmentasi}

Pada pengujian ini sistem hasil segmentasi citra akan diberikan variable pemotongan citra yang beragam dari 17 bagian hingga 21 bagian masing-masing 5 kali untuk menguji keakuratan garis penentu lebar bahu pinggang dan panggul.

Tabel 6. Hasil Pengujian Segmentasi

\begin{tabular}{|c|c|c|c|c|}
\hline No. & \multirow{2}{*}{ Citra hasil pembagian } & \multicolumn{3}{|c|}{ Garis ke- } \\
\hline Pengujian & & Bahu & Pinggang & Panggul \\
\hline $\begin{array}{c}01 \\
\text { (17 Garis) }\end{array}$ & & $\begin{array}{c}\text { Garis } \\
\text { tidak } \\
\text { mewakili } \\
\text { bahu }\end{array}$ & $\begin{array}{c}\text { Garis tidak } \\
\text { mewakili } \\
\text { pinggang }\end{array}$ & 9 \\
\hline $\begin{array}{c}02 \\
\text { (18 Garis) }\end{array}$ & & 4 & 8 & $\begin{array}{c}\text { Garis tidak } \\
\text { mewakili } \\
\text { panggul }\end{array}$ \\
\hline $\begin{array}{c}03 \\
\text { (19 Garis) }\end{array}$ & & 4 & 8 & 10 \\
\hline $\begin{array}{c}04 \\
\text { (20 Garis) }\end{array}$ & & $\begin{array}{c}\text { Garis } \\
\text { tidak } \\
\text { mewakili } \\
\text { bahu }\end{array}$ & 9 & 11 \\
\hline
\end{tabular}




\begin{tabular}{|c|c|c|c|c|}
\hline \multirow{2}{*}{$\begin{array}{c}\text { No. } \\
\text { Pengujian }\end{array}$} & \multirow{2}{*}{ Citra hasil pembagian } & \multicolumn{3}{|c|}{ Garis ke- } \\
\hline & & Bahu & Pinggang & Panggul \\
\hline $\begin{array}{c}05 \\
\text { (21 Garis) }\end{array}$ & & $\begin{array}{c}\text { Garis } \\
\text { tidak } \\
\text { mewakili } \\
\text { bahu }\end{array}$ & 9 & $\begin{array}{c}\text { Garis tidak } \\
\text { mewakili } \\
\text { panggul }\end{array}$ \\
\hline
\end{tabular}

Dari hasil pengujian diatas dapat disimpulkan bahwa pembagian garis yang tepat pada bagian tubuh ada pada pembagian tubuh dengan 19 garis.

\subsection{Pengujian klasifikasi bentuk badan}

Pengujian akan dilakukan dengan memberi input berupa citra bentuk badan lalu diberikan rekomendasi bentuk badan yang sesuai

Tabel 7. Hasil Pengujian Klasifikasi Bentuk Badan

\begin{tabular}{|c|c|c|c|c|c|c|c|c|}
\hline \multirow{2}{*}{ Pengujian } & \multicolumn{3}{|c|}{ Ukuran badan asli (cm) } & \multirow{2}{*}{$\begin{array}{l}\text { Deteksi } \\
\text { bentuk tubuh } \\
\text { sebenarnya }\end{array}$} & \multicolumn{3}{|c|}{ Ukuran pada citra $(\mathrm{cm})$} & \multirow{2}{*}{$\begin{array}{c}\text { Deteksi } \\
\text { bentuk } \\
\text { tubuh sistem }\end{array}$} \\
\hline & Bahu & Pinggang & Panggul & & Bahu & Pinggang & Panggul & \\
\hline 1 & 35 & 27 & 32 & Segitiga Terbalik & 41,82 & 34,17 & 36,21 & $\begin{array}{l}\text { Segitiga } \\
\text { Terbalik }\end{array}$ \\
\hline 2 & 40 & 36 & 40 & Jam Pasir & 44,88 & 37,23 & 44,88 & Jam Pasir \\
\hline 3 & 40 & 26 & 38 & Segitiga Terbalik & 41,82 & 32,13 & 36,21 & $\begin{array}{l}\text { Segitiga } \\
\text { Terbalik }\end{array}$ \\
\hline 4 & 43 & 26 & 35 & Segitiga Terbalik & 42,84 & 32,64 & 36,72 & $\begin{array}{l}\text { Segitiga } \\
\text { Terbalik }\end{array}$ \\
\hline 5 & 37 & 35 & 40 & Segitiga & 61,2 & 50,49 & 46,41 & $\begin{array}{l}\text { Segitiga } \\
\text { Terbalik }\end{array}$ \\
\hline 6 & 41 & 27 & 32 & Segitiga Terbalik & 38,25 & 38,25 & 37,74 & $\begin{array}{l}\text { Segitiga } \\
\text { Terbalik }\end{array}$ \\
\hline 7 & 38 & 25 & 33 & Segitiga Terbalik & 43,86 & 32,64 & 42,33 & $\begin{array}{l}\text { Segitiga } \\
\text { Terbalik }\end{array}$ \\
\hline 8 & 47 & 31 & 32 & Segitiga terbalik & 45,9 & 57,12 & 53,55 & Segitiga \\
\hline 9 & 45 & 34 & 37 & Segitiga Terbalik & 46,41 & 37,23 & 44,37 & $\begin{array}{l}\text { Segitiga } \\
\text { Terbalik }\end{array}$ \\
\hline 10 & 49 & 35 & 40 & Segitiga Terbalik & 48,45 & 37,74 & 45,9 & $\begin{array}{l}\text { Segitiga } \\
\text { Terbalik }\end{array}$ \\
\hline 11 & 48 & 45 & 52 & Segitiga & 47,94 & 42,84 & 52,02 & Segitiga \\
\hline 12 & 47 & 54 & 48 & Segitiga & 47,43 & 47,43 & 49,98 & Segitiga \\
\hline
\end{tabular}

Setelah dilakukan pedeteksian bentuk badan, sistem juga akan mengeluarkan output berupa rekomendasi pakaian sesuai dengan bentuk badan yang terdeteksi. Dari hasil pengujian diatas dapat disimpulkan bahwa 9 dari 11 pengujian deteksi sama dengan bentuk badan asli. Sehingga dapat ditarik kesimpulan bahwa sistem ini memiliki akurasi deteksi bentuk badan dan merekomendasikan pakaian sebesar $82 \%$. Terjadi kesalahan sebesar $18 \%$ karena partisipan pengujian tidak menggunakan pakaian yang sudah ditentukan atau pengambilan citra dengan jarak kamera yang tidak sesuai oleh partisipan.

\section{KESIMPULAN}

Setelah melakukan pengujian pada sistem ini, maka diperoleh akurasi deteksi manusia sebesar $97,00 \%$ oleh sumber data online dan hasil foto langsung, $82,0 \%$ dari Human Detection 
Deteksi Manusia menggunakan Pre-Trained MobileNet untuk Segmentasi Citra Menentukan Bentuk Tubuh

Database, dan 98,0\% dari CrowdHuman. Hasil deteksi tersebut memiliki akurasi lebih besar dibandingkan depngan pre-trained Mobilenet yang telah diujikan dengan Pascal VOC2012 dengan akurasi sebesar 80,25\%. Sistem memiliki jarak optimal pada objek 2 meter dengan ketinggan kamera 0,75 meter yang berdasarkan rata-rata akurasi terbesar sebesar $96,06 \%$ dan akurasi hasil deteksi bentuk badan sebesar $82 \%$ dari pengujian sebanyak 11 partisipan.

\section{DAFTAR RUJUKAN}

Andrew G. Howard, M. Z. (2017). MobileNets: Efficient Convolutional Neural Networks for Mobile Vision Applications.

Brownlee, J. (2019, January). A gentle Introduction to Batch Normalization for Deep Neural Networks

Daniel, H. P., \& Kauffman, M. J. (2009). Exceptional Learners An Introduction to Special Education.

D. M. Anisuzzaman, M. H. (2019). Online Trial Room based on Human Body Shape Detection.

I.J. Image, Graphics and Signal Processing

Everingham, M. V. (2012). Visual Object Classes Challenge 2012 (VOC2012). Retrieved from

Pascal 2: http://host.robots.ox.ac.uk/pascal/VOC/voc2012/

Karla Simmons, C. L. (2004). Female Figure Identification Technique (FFIT) for Apparel. Journal of Textile and Apparel, Technology and Management.

Koukoravas, K. (2018, August 23). How to find clothes that suit your body type with Intelistyle, The A.I. Personal Stylist. Diambil kembali dari intelistyle.com: https://www.intelistyle.com/find-clothes-suit-body-type/

Loh, W. Y. (2014). Classification and Regression Tree Methods. Willey StatsRef : Statistic Reference Online.

Mark Sandler, A. H.-C. (2019). MobileNetV2: Inverted Residuals and Linear Bottlenecks.

Monica Stella Angelina, P. T. (2015). Analisis Semiotik Fashion Ines Ariani. Jurnal Komunikasi, 165-179.

Pedomanti D (2018). Comparison of non-linear activation functions for deep neural network on MNIST classification task

Saha, S. (2018, 12 16). A Comprehensive Guide to Convolutional Neural Networks - the ELI5 way.

Shuai Shao, Z. Z. (2018). CrowdHuman: A Benchmark for Detecting Human in a Crowd Widyosiswoyo, Hariwijaya Soewandi (1991). Ilmu Alamiah Dasar. Ghalia Indonesia, Jakarta Timur 